\title{
Barriers and Facilitators of the Teaching-Learning Process of Medical Students in Primary Care in the City of São Paulo
}

\section{Barreiras e Facilitadores do Processo Ensino-Aprendizagem de Estudantes de Medicina na Atenção Primária, no Município de São Paulo}

\author{
Moniquelly Barbosa da Silva ${ }^{I}$ (iD \\ Izabel Rios ${ }^{I, I}(\mathbb{D}$ \\ Pedro Félix Vital Júnior ${ }^{I}$ (iD \\ Andréa Tenório Correia da Silva ${ }^{I, I I}$ (ID
}

\section{KEYWORDS}

- Medical Education.

- Primary Health Care.

- Learning.

- Health Personnel.

- Community Health Workers.

- Qualitative Research.
${ }^{\mathrm{I}}$ Faculdade Santa Marcelina, São Paulo, São Paulo, Brazil.

${ }^{\text {II }}$ Universidade de São Paulo, São Paulo, São Paulo, Brazil.

\section{ABSTRACT}

Introduction: Although Primary Health Care (PHC) is essential for medical students' training, the perceptions of primary care workers about the teaching-learning process have been overlooked, particularly in municipalities where PHC management is performed by a private organization instead of the government, such as in the city of São Paulo. Objective: to analyze the perceptions of primary care workers about barriers and facilitators of medical students' teaching-learning process in PHC in the city of São Paulo. Method: we conducted a qualitative research. We performed in-depth interviews with 12 primary care workers from the family health teams (four physicians, four nurses and four community health workers), who worked in primary care clinics in the east region of the city and received medical students, from $1^{\text {st }}$-year to internship students. The interviews were recorded, transcribed and afterwards, they were repeatedly read. We identified thematic units following the content analysis principles. Results: the barriers to medical students' teaching-learning process in PHC were the following: (1) excessive number of scheduled patients and scarcity of time for discussion; (2) inadequate infrastructure of primary care clinics; (3) lack of training; and (4) ineffective integration among faculty, healthcare workers, managers and the assisted population. The facilitating factors of the teaching-learning process were: (1) high quality of healthcare services; (2) integration among primary care teams, interdisciplinary teams, and students; and (3) well-trained medical preceptors. Conclusions: our results have implications for PHC professionals, educational institutions, and managers. The improvement of the integration among educational institutions, health services managers, primary care workers, and the population is a condition to reach the effectiveness in the teaching-learning process, and to ensure the development of essential competencies for PHC assistance quality. Thus, the training of health professionals, improving the primary care clinic infrastructure, and creating strategies to ensure enough time for discussion and feedback could contribute to mitigate barriers to medical students' teaching-learning process in PHC. 


\section{PALAVRAS-CHAVE}

- Educação Médica.

- Atenção Primária à Saúde.

- Aprendizagem.

- Pessoal de Saúde.

- Agentes Comunitários de Saúde.

- Pesquisa Qualitativa.

\section{RESUMO}

Introdução: Apesar de a atenção primária à saúde (APS) ser essencial para a formação médica, as percepções dos profissionais das equipes de saúde da família (eSF) sobre o processo ensino-aprendizagem foram pouco estudadas, em particular em municípios nos quais o modelo de gestão da APS é indireto, como na cidade de São Paulo. O objetivo deste estudo foi analisar as percepções de profissionais das eSF sobre as barreiras e os facilitadores do processo ensino-aprendizagem dos estudantes de medicina na APS, no município de São Paulo. Método: Trata-se de uma pesquisa qualitativa. Foram realizadas entrevistas semiestruturada com 12 profissionais das eSF (quatro médicos, quatro enfermeiros e quatro agentes comunitários de saúde), que atuavam em unidades básicas de saúde (UBSs) localizadas na zona leste do município de São Paulo e que recebiam estudantes de Medicina do primeiro ano ao internato. As entrevistas foram gravadas e transcritas, lidas e relidas, sendo identificadas unidades de significado de acordo com os pressupostos da análise de conteúdo. Resultados: Os entrevistados destacaram as seguintes barreiras relacionados ao processo ensinoaprendizagem na APS: 1. excesso de pacientes agendados e escassez de tempo para discussão do caso com os estudantes; 2. inadequada estrutura física do serviço de saúde; 3. falta de preparação dos profissionais; e 4. falta de articulação ensino-serviço-comunidade. Os aspectos reconhecidos como fatores facilitadores do processo ensino-aprendizagem foram: 1. qualificação do serviço de saúde e da equipe; 2. integração com a eSF e com equipe multiprofissional; e 3. preparação dos preceptores médicos. Conclusões: Os resultados têm implicações para os profissionais da APS, as instituições de ensino superior e os gestores da saúde da APS estudados. O aprimoramento das relações e articulações entre as instituições de ensino, os gestores dos serviços de saúde, os profissionais de saúde e a comunidade é condição necessária para efetivar o processo ensino-aprendizagem e garantir o desenvolvimento de competências para a qualidade do cuidado na APS. Assim, o preparo dos profissionais de saúde, a adequação do espaço físico da UBS, a reflexão sobre o agendamento e estratégias para garantir tempo para discussão do caso e espaço para feedback podem contribuir para mitigar as barreiras ao processo ensino-aprendizagem na APS.

Received on 12/03/19

Accepted on $03 / 12 / 20$

\section{INTRODUCTION}

The teaching-learning model proposed by the National Curriculum Guidelines (NCG) for the 2014 Medical undergraduate course recommends an increase in the workload of internships in Primary Health Care (PHC) and postulate that the essential contents of the undergraduate course in medicine should establish a dialogue with the main health needs identified in the population, allowing the early inclusion of students in practical activities, as well as the use of different teaching-learning scenarios ${ }^{1}$. Primary Health Care is a privileged teaching-learning context for the understanding of the population's health needs and for the student to experience a set of actions associated to care, from the treatment of illnesses, disease prevention and health promotion to health management, such as teamwork, care coordination, and articulation of care networks in the Brazilian National Health System (SUS, Sistema Único de Saúde) $)^{2-4}$. In this sense, some of PHC contributions to medical education would be: dealing with different contexts and life cycles of the assisted population, their clinical, social and cultural complexities; constituting a scenario of practices in which the integration of different fields of knowledge occurs and favoring integrated and interdisciplinary clinical practice; allowing the understanding of the intersectoral health care network; contributing to the development of cultural competence and health communication; and dealing with complex problems continuously and longitudinally. Thus, health professionals who work in $\mathrm{PHC}$ are essential for training doctors in the perspective of comprehensiveness, equity and humanization.

In 1994, the Ministry of Health created the Family Health program to promote the reorganization of Primary Care in Brazil. The Family
Health teams (FHT) comprise physicians, nurses, nurse technicians and community health workers (CHW), and are currently responsible for the coverage of more than 132 million individuals across the national territory. These are the teams that welcome the majority of medical students from both public and private educational institutions, and these professionals undertake the activities that these students carry out at the BHU, in the territory and in the homes of the enrolled population ${ }^{2,5,6}$. Even in the face of this scenario, very few studies have investigated the perceptions of professionals from family health teams about aspects and/or conditions that can affect the teaching-learning process of medical students in the PHC. A survey described the perceptions of doctors, nurses, dentists, nurse technicians and community health workers about the inclusion of medical students in family health teams in the municipality of Montes Claros, state of Minas Gerais, Brazil. One of the problems described in the focal groups was the high number of students per PCU, which hindered the team's planning and the professionals' relationship with the students ${ }^{5}$.

A condition that could have implications for the teaching-learning process is the current management model of Primary Care services in the municipality. For instance, the direct management of the Primary Care Units by the Municipal Health Secretariat (MHS), as in the case of the municipality of Montes Claros (MG) mentioned in the paragraph above, where the hiring of professionals for the family health teams occurs through civil service examinations, which differs from the indirect management model, in which the MHS hires employees through private institutions, such as social organizations, which manage PHC services, as it occurs in the city of São Paulo ${ }^{7}$. In this case, the hiring of professionals

REVISTA BRASILEIRA DE EDUCAÇÃO MÉDICA

2 44 (2) : e065; 2020 
for family health teams are carried out by these SMS partner institutions ${ }^{8}$. The management model adopted by the municipality can affect the teaching-learning scenarios in PHC. For example, the high turnover of physicians in family health teams in the city of São Paulo, described in the research carried out by Campos and $\mathrm{Malik}^{8}$, can be a barrier to the activities developed by medical students during their internships in $\mathrm{PHC}^{9}$.

Since the creation of the scenario for the teaching-learning process in PHC depends intrinsically on the associations that are established between higher education institutions, health service managers, health professionals who work in basic health units and the assisted population ${ }^{2,5,10,11}$, it becomes essential to investigate the perceptions of professionals from family health teams about the teaching-learning process in municipalities where the current PHC management model is an indirect one.

Therefore, the aim of this research is to investigate barriers or facilitators of the teaching-learning process for medical students in PHC, according to the perceptions of physicians, nurses and community health agents in the city of São Paulo. In relation to the studies previously carried out on the subject, the current study adds the investigation in the teaching-learning scenario in PHC in a municipality of which model of PHC service management is the indirect model, via private institutions called social organizations. Moreover, this is one of the few studies investigating the perceptions of CHWs about the medical students' teaching-learning process, even though they are key professionals for this process ${ }^{12}$. Therefore, studying the perceptions of CHWs about the teaching-learning process can contribute to improving the teachingservice-community relationships and impact on the internship quality. The aim here is to broaden the understanding of the aspects that can affect the teaching-learning process, barriers and facilitators, and, thus, contribute so that higher education institutions, health service managers and health professionals can develop actions aimed at the improvement of the teaching-learning process.

\section{MATERIAL AND METHODS}

According to the objectives of the present study, which seeks to understand the meanings of social world phenomena ${ }^{13}$, a qualitative methodological design was chosen. According to Minayo ${ }^{14}$, the qualitative methodology allows a more adequate approach to the study of research objects constituted by meanings, motives, aspirations, beliefs, values and attitudes, on which complex relationships and processes cannot be reduced to the quantitative perspective.

Data production took place in Primary Care Units in the East Zone of the city of São Paulo, which receive medical students from the $1^{\text {st }}$ to the $11^{\text {th }}$ semesters of the medical course. The research subjects were chosen according to qualitative selection criteria that characterize them as good key informants, that is, people capable of expressing their opinions well and who are recognized for their role in the environment where they work. They were 12 health professionals (4 physicians, 4 nurses and 4 community health workers) who worked in family health teams in the East Zone of the city of São Paulo, and actively work in the teachinglearning process, supervising medical students during the internship. The PCUs where these professionals worked were managed by an MHS partner institution, Casa de Saúde Santa Marcelina.

The researchers included a medical internship student and two teachers from the Primary Health Care and Family and Community
Medicine module, who do not work in the PCU assessed by this study or in the social organization that managed these health services. Participants were presented with the Free and Informed Consent (FIC) form, which guarantees the privacy and confidentiality of the interviews. The field research was carried out by the student, after training and supervision to work as a researcher.

The technique chosen for data production was the in-depth interview. This choice is justified because it is a technique that allows interaction between the researcher and the interviewee, in which the first stimulates the reflection of the second about what is being investigated. In this intersubjective process, the researcher's understanding of how respondents perceive and interpret the object of study is deepened. According to the in-depth interview technique, the researcher asks openended questions, encouraging the interviewee to discuss the proposed topic. The interviewer is able to conduct the discussion for the researched topic and for the objectives to be attained, elucidating questions and clarifying doubts ${ }^{15}$. The in-depth interview technique also showed to be operationally more viable in this study, considering the professionals' different working hours, as well as their time availability.

Open question scripts were created for the interviews (appendix 1), considering the perspective view of the topic by health users and professionals. The interviews were carried out at the BHU at pre-scheduled times, being recorded and later transcribed and checked.

Data analysis was performed by reading and rereading the transcribed material for identification and grouping of units of meaning and construction of the analysis categories, according to the content analysis technique. This stage of the research was carried out by the three researchers. Consensus and dissent from all interpreters were considered. The analyses were carried out by the thematic grouping of the empirical material produced from the transcribed material of the health professionals' interviews. These categories are shown in Table 1.

This study is the result of the Scientific Initiation research linked to the Research Center in Primary Care and Implementation Science (NUPAScience), Santa Marcelina School of Medicine. The research was approved by the Research Ethics Committee of the Health Secretariat of the municipality of São Paulo (Opinion number 2,457,572) and by the Ethics Committee of Faculdade Santa Marcelina (Opinion number 2,423,305).

\section{Table 1}

Thematic categories based on the reading and rereading of the transcribed material.

Thematic categories

1. Schedule and consultation time 2. Physical structure of the health service Barriers to the teaching learning process

3. Lack of professionals' training

4. Lack of articulation between teaching, service and community

1. Qualification of the health service and the team

Facilitators of the teaching- 2. Integration with the FHT and with a

learning process multidisciplinary team

3. Training of medical preceptors

Source: Created by the authors of this study, based on the interview data.

REVISTA BRASILEIRA DE EDUCAÇ̃̃o MÉDICA

3 44 (2) : e065; 2020 


\section{RESULTS AND DISCUSSION}

Twelve health professionals were interviewed (four doctors, four nurses and four community health agents) who worked in family health teams in the East Zone of the city of São Paulo and who received and supervised medical students during their internship at PHC. All of these professionals were hired by the same social organization, Casa de Saúde Santa Marcelina. Nine respondents were women. The age of these professionals varied from 25 to 44 years and the individual monthly income varied between $\mathrm{R} \$ 1,600.00$ and $\mathrm{R} \$ 18,000.00$.

Based on the reading and rereading of the transcribed material, the following thematic categories emerged, related both to the barriers and to the conditions considered to be facilitators of the teaching-learning process.

\section{Barriers to the teaching-learning process in PHC}

- Schedule and restricted time to carry out the consultation: One of the barriers highlighted by professionals in the learning and training process of students concerns the time for discussing cases and conducts with the students, as well as for explaining any doubts and, above all, the disease itself and its implications. In this sense, Kwa and Rafidah ${ }^{16}$ postulate that scarce time, the conflicting demands that may come from students and patients, are challenges for teaching in PHC. In the municipality of São Paulo, according to the recommendations of the Municipal Health Secretariat, physicians have a fixed schedule of 15 minutes to carry out the consultation, regardless of whether the PCU receives students or not.

[...] the biggest difficulty is the lack of time. The professional's schedule is not a "protected" schedule. We don't have time to discuss the cases, to help, to follow-up all the consultations [...] the changes (in the schedule) are not supported by the city hall, by the Health Secretariat, do you understand? They do not give the authorization, and we end up making an adaptation, but we cannot have the ideal time to discuss the cases (Physician 3).

Time is very busy. As the scheduled appointments last only 15 minutes, it is very busy. It is welcoming regarding other things (CHW2).

I think time is a difficulty, because we have a very fixed schedule, you know, every 15 minutes, and it is often difficult with this time, with us alone. And you have to explain it to a student, spend more time with that. When the physician is a preceptor, the consultation time should be increased a little and decrease the number of consultations they carry out. Time is the biggest limiting factor, for sure (Physician 2).

- Insufficient physical structure: Some problems and challenges regarding the PHC's ability to meet the minimum requirements necessary for adequate medical training appeared in this study. Such problems are described in the national literature. In brief, there is an emphasis on the lack of adequate structure in the PCU to receive these students; little time available for medical care: "the physical structure, I think it is also important. We have very small offices. An insufficient number of offices as well" (Physician 3).

For the integration between teaching and service to be successful, some prerequisites are necessary, both in the agreement signed between the university and the health service, and in the physical capacity of the network. The network must be ample, organized and efficient, a situation that is very distant from the reality we live in ${ }^{17}$. The lack of infrastructure in the PCU makes the teaching-learning process more difficult ${ }^{9}$. Other authors have emphasized the importance of providing physical space in $\mathrm{PHC}$ services, not only to assist patients, but also to conduct more in-depth case discussions and provide feedback to students with greater privacy ${ }^{16}$.

- Lack of training of the professionals who received the students: Some authors emphasize the importance of having sufficient staff, with adequate training and motivation to supervise students, highlighting the need for preceptors with technical training, specific training and who already have a profile of attitudes that can be used as examples for future professionals ${ }^{17}$.

A survey was carried out with managers/coordinators of medical courses in several regions of Brazil and reported that the inadequate training of teachers is a factor that hinders the development of students' skills to work in Primary Care'.

Among the participants of the present study, the CHAs described that they received no training for the teaching-learning process. In general, they are only informed of the students' arrival and that they will perform specific activities with them, such as going out on home visits. There is insufficient education and training of the professionals responsible for carrying out the teaching-learning process: "No. We do not receive training. The doctor tells you beforehand [...]" (CHW 1).

- Lack of teaching-service-community articulation: The connection is important for establishing interpersonal bonds that are crucial for the quality of care, and for the professional to perceive physical, mental and social needs, among several other characteristics that contribute to improve the quality of the service provided and the medical training itself $\mathrm{f}^{17}$. Although the interviewed health professionals describe the importance of the bond of trust that is established in a team and between the latter and the BHU users, as Nurse 4 states, the lack of communication with users about the arrival and presence of students in the BHU can weaken the bond, and what happens in practice is that, very often, the user is suddenly placed in the situation of being treated by the student without a previous contextualization by the team professionals, affecting the user's expectation of having the consultation carried out by the physician who they are already familiarized with and connected to; this generates oddness, discomfort and dissatisfaction by the user (as Nurse 1 says).

[...] Here we have the connection, which is a very strong part of the strategy. We enter the patient's home, we are part of their life, within their family [...]. (Nurse 4)

[...] there is a patient who, for instance, has a good relationship with the physician, then they arrive and will not have a consultation with this physician (but with a student, instead [...] they complain about it a lot [...]. (Nurse 1)

Facilitators of the teaching-learning process

- Education of the health service and staff: It is understood that the presence of the medical student in the team improves the quality of the service, since it encourages professionals to reflect and encourages them to think about their reasoning and decisions, avoiding a state of automatism and pragmatism in decision-making. The model of care and

REVISTA BRASILEIRA DE EDUCAÇÃO MÉDICA

4 44 (2) : e065; 2020 
teaching more focused on continuing education, favoring the discussion of cases with the multiprofessional team, would achieve greater coverage and justification of conducts, reduce errors and improve care ${ }^{5}$. Physicians, nurses and community health workers who participated in this study agree with such impacts, highlighting that the student's presence improves the service and promotes the development of characteristics and skills previously not noticed by the team:

[...] they discuss the conduct with us. This also results in a gain in quality. Often, they end up having a viewpoint that not even the preceptors had noticed themselves [...] it ends up giving a greater wealth of details, a greater wealth of possibilities. And sometimes a point of view, a more distinctive perspective [...]. (Physician 1)

[...] every time you're going to do something...Look, I'm doing this, because of that. It brings us back to theory. It makes us kind of recycle. You kind of have to start justifying why you're doing that [...]. (Nurse 1)

[...] when there is a student, the community agent brings a more grounded story, with more content, so that they can include the student, let the student learn about it [...]. (Nurse 3)

Such behavior by the team also applies to the relationship with the community, highlighting that with the inclusion of students, the team became more welcoming and receptive to patients. They perceive that the population feels more supported when there are students at the BHU, since they associate a higher quality of service and professionals to a place where an educational institution entrusted the learning of its students. A study ${ }^{18}$ described the patients' perception of having students at the BHU: patients felt more welcomed, received better and more detailed explanations about their disease and its treatment in the presence of students. This improvement in quality of care was attributed to greater availability of time for the examination and discussions about the disease between the tutor and the students during the provision of care.

[...] the patients like it a lot, because you have more time to explain about the pathology [...] they feel more assisted, because consultations with students always require more time [...] they feel appreciated, welcomed [...] (Physician 4)

Community health agents also reported that the presence of students during home visits is positive, because it brings credibility to the population that feels safer when the $\mathrm{CHW}$ is accompanied by the student, contributing to the improvement of the service-community connection ${ }^{19}$ : "It brings many benefits. It brings credibility for the population, helps us to actively search [...] it's a positive thing [...]" (CHW 1).

Moreover, there is a construction of knowledge and meaning in the student's presence in the daily life of the CHW, contributing to the health education of these professionals, since it is a group with many uncertainties related to their skills, competencies and knowledge and, largely marginalized in terms of health education and training ${ }^{19}$ : "There are times when they bring doubts with their views as students and they end up solving things for us as well [...]" (CHW 3).

- Integration with the FHT Team and with a multidisciplinary team: Some authors point out that the dialogue between work and education takes place in spaces where the teaching-service-community axis establishes a confluence of knowledge and ways of seeing the world ${ }^{20}$. A study evaluated the perception of medical students about the internship in PHC, and the participants mentioned the importance of PHC in the medical training process ${ }^{21}$. The integration of the medical student who is presented to the community at an early stage helps the training of a more complete professional, aware and participative in the social reality found in the outskirts of the city and able to integrate a multiprofessional team: "after the students started coming to the unit, the team changed its attitude as well. The team understood better what this student's role is on the team [...] and the students integrated very well [...]" (Physician 3 )

For the interviewed professionals, the integration of the students and the team takes place effectively, with the professionals understanding the student's role within the team. They also observe a transformation of the medical professionals, who start having a "more distinctive perspective" regarding their power of effectiveness and the quality of care.

From the viewpoint of the medical professional training in the FHT, interdisciplinary development is sought, which involves all knowledge as being equally important, with permanent improvement in the quality of health care and the humanization of care. Interdisciplinarity is experienced by students in health promotion groups, in which the student is included in the universe of the community, in the interaction with the CHWs during home visits, in medical and nursing consultations.

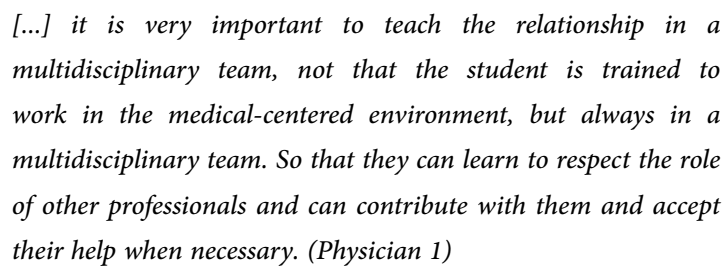

The reformulation of medical education calls for greater capacity of integration with the community and the acquisition of socio-cultural skills. The context of the student's immersion in the community, especially through home visits with the CHWs, shows a world that is often unknown and distant from the student's reality, changing their view into a broader and more complete one of the medical and social reality.

[...] they connect as well. They begin to understand a problem ... the problem that the community, that society has. Problems that many have not experienced, they do not live in those places... they end up understanding a little of this social problem, wanting to help [...] (CHW2).

- Training of preceptors: When asking the interviewed professionals about specific training or skills, only medical professionals stated that they had gone through some training before the students arrived. These professionals also declared that they participated in monthly meetings, with refresher courses and continuing education to perform the preceptorship.

[...] we were informed, and we went through the training before receiving them at the time. (Physician 3 )

[...] we have monthly meetings with supervisors, with the teachers [...] we are always attending meetings, always on an refresher course. (Physician 4)

$5 \mid$\begin{tabular}{l|l} 
REVISTA BRASILEIRA DE EDUCAÇÃO MÉDICA \\
\hline 44 (2) : e065; 2020
\end{tabular} 


\section{Study limitations}

The present study has limitations, including the fact that the participants are hired by the same social organization, Casa de Saúde Santa Marcelina, which has a tradition in teaching and research in PHC services in the east zone of the city of São Paulo. We did not interview professionals who worked in other institutions, in other regions of the municipality. Another limitation is that we did not perform triangulation through data collection and analysis of the medical students', faculty members' and health care system managers' perceptions.

\section{FINAL CONSIDERATIONS}

The inclusion of medical students in Primary Health Care provides the acquisition and development of skills and essential qualities in the training of a medical professional to provide effective, comprehensive and humanistic care, with health professionals working in PHC the key elements for the teaching-learning process. Nevertheless, there have been few studies that analyzed the perceptions of these actors about this process and, particularly, we found only one study that included the CHW when analyzing the perceptions of professionals about the inclusion of students in PHC. Moreover, the municipalities have the autonomy to decide which PHC service management model should be adopted, whether direct or indirect, which might have consequences in the practice scenarios. This study assessed the perceptions of users, community agents, physicians and nurses who work in Primary Care in the city of São Paulo, which has an indirect PHC management model, about barriers and facilitators of the teaching-learning process of undergraduate medical students.

Considering the barriers to the teaching-learning process identified in this research, strategies to overcome them include, first, promoting the assessment of the adequate physical structure, the management of spaces for care provision, such as the optimization of the BHU room map, for discussion of cases and to carry out periodic feedback for students, as well as promoting the discussion and the creation of a protected schedule and aimed at teaching, maintaining the necessary time for case discussion, avoiding the overload of the professionals from the family health teams involved in the teaching-learning process, and patients' complaints about waiting time. The improvement of relationships and integration between educational institutions and health service managers is a necessary condition for the effectiveness of the teaching-learning process and to guarantee the development of skills for the quality of care in PHC. The presence of professionals, not only physicians, trained and capable of effectively contributing to medical education, is a frequently neglected necessity, which ends up taking the teaching model back to the medical-centered one. Another crucial point is the teachingservice-community integration, improving users' understanding of the importance of having students in a health service and its meanings, in addition to providing spaces for conversation so that users can present their doubts and reflections on the student's presence and the teachinglearning process of which the student, the health professional and the user are part. Therefore, the results have implications for teachers, health professionals who welcome the students, health service managers and medical education managers, and describe key points for the improvement of the teaching-service-community integration in a region of the municipality of São Paulo.

\section{ACKNOWLEDGEMENT}

We acknowledge all the support of the Primary Health Care team, Casa de Saúde Santa Marcelina, the Health Secretariat of the municipality of São Paulo, particularly, the Coordenadoria Regional de Saúde Leste. This study is the result of the Scientific Initiation research linked to the Research Center in Primary Care and Implementation Science (NUPAScience), Santa Marcelina School of Medicine.

\section{REFERENCES}

1. Brasil. Conselho Nacional de Educação. Câmara de Educação Superior. Resolução CNE/CES no 3, de 20 de junho de 2014. Institui Diretrizes Curriculares Nacionais do Curso de Graduação em Medicina e dá outras providências. Diário Oficial [da] República Federativa do Brasil, Brasília, DF; 23 jun 2014; Seção 1, p. 8-11 [acesso em 16 nov 2018]. Disponível em: http://portal.mec.gov.br/index. php?option=com_docman \&view=download $\&$ alias $=15874$-rces00314\&Itemid=30192.

2. Vieira JE, Elias PEM, Benseñor IJM, Grisi SJE. Instalação da disciplina de Atenção Básica em Saúde na Faculdade de Medicina da Universidade de São Paulo (2003-2006). Rev. bras. educ. med. 2007;31(3):236-44 [acesso em 10 jul 2018]. Disponível em: http://www.scielo.br/scielo. php?script=sci_arttext\&pid=S0100-55022007000300006\&lng=en\&nr $\mathrm{m}=\mathrm{iso} \& \mathrm{tlng}=\mathrm{pt}$.

3. Inez $\mathrm{M}$, Anderson P, Demarzo M, Rodrigues RD. A medicina de família e comunidade, a atenção primária à saúde e o ensino de graduação. Rev. bras. med. fam. comunidade 2007;3(11):1-32.

4. Demarzo MMP, Almeida RCC de, Marins JJN, Trindade TG da, Anderson MIP, Stein AT, et al. Diretrizes para o ensino na atenção primária à saúde na graduação em medicina. Rev. bras. educ. med 2012;36(1):143-8 [acesso em 14 set 2018] Disponível em: http://www.scielo.br/scielo.php?script=sci_arttext \&pid=S0100$55022012000100020 \& \operatorname{lng}=\mathrm{en} \& \mathrm{nrm}=\mathrm{iso} \& \operatorname{lng}=$ pt.

5. Caldeira ÉS, Leite MT de S, Rodrigues-Neto JF. Estudantes de Medicina nos serviços de atenção primária: percepção dos profissionais. Rev. bras. educ. med. 2011;35(4):477-85 [acesso em 12 fev 2019]. Disponível em: http://www.scielo.br/scielo.php?script=sci_ arttext\&pid=S0100-55022011000400006.

6. Brandão ERM, Rocha SV, Silva SS da. Práticas de integração ensinoserviço-comunidade : reorientando a formação médica. Rev. bras. educ. med. 2013;37(4):573-7.

7. Coelho VSP, Greve J. As organizações sociais de saúde e o desempenho do SUS: um estudo sobre a atenção básica em São Paulo. Dados 2016; 59(3):867-901 [acesso em 6 out 2019]. Disponível em: http://www.scielo.br/scielo.php?script=sci_arttext\&pid=S0011$52582016000300867 \& \operatorname{lng}=$ pt\&tlng=pt.

8. Campos CV de A, Malik AM. Satisfação no trabalho e rotatividade dos médicos do Programa de Saúde da Família. Rev Adminstração Pública 2008;42(2):374-68.

9. Vieira S de P, Pierantoni CR, Magnago C, Ney MS, Miranda RG de. A graduação em Medicina no Brasil ante os desafios da formação para a atenção primária à saúde. Saúde debate 2018;42:189-207.

10. Silva ATC da, Medeiros Junior ME de, Fontão P de N, Saletti Filho HC, Vital Junior PF, Bourget MMM, et al. Medicina de Família do primeiro ao sexto ano da graduação médica: considerações sobre uma 
proposta educacional de integração curricular escola-serviço. Rev. bras. educ. med. 2017;41(2):336-45 [acesso em 3 jan 2018]. Disponível em: http://www.scielo.br/scielo.php?script=sci_arttext\&pid=S0100$55022017000200336 \& \operatorname{lng}=\mathrm{pt} \& \ln \mathrm{g}=\mathrm{pt}$.

11. Cassel C, Wilkes M. Location, location, location: where we teach primary care makes all the difference. J. gen. intern. med. 2017;32:4115 [acesso em 15 abr 2019]. Disponível em: http://link.springer. com/10.1007/s11606-016-3966-x.

12. Pereira JG, Regina W, Martines V, Chueiri PS. Integração academia, serviço e comunidade: um relato de experiência do curso de graduação em Medicina na atenção básica no município de São Paulo. Mundo saúde 2009;33(1):99-107.

13. Neves J. Pesquisa qualitativa: características, usos e possibilidades. Cad Pesq em Adm São Paulo 1996;1(3):1-5.

14. Minayo MC de S. O desafio do conhecimento: pesquisa qualitativa em saúde. São Paulo: Hucitec; 1993.

15. Boni V, Quaresma S. Aprendendo a entrevistar: como fazer entrevistas em Ciências Sociais. Em Tese 2005;2(3):68-80.

16. Kwa $S$, Yong Rafidah A. Notes for the primary care teacher: teaching in the family practice clinics. Malays Fam Physician2008;3(2):101-3 [acesso em $1^{\circ}$ out 2019]. Disponível em: http://www.ncbi.nlm.nih. gov/pubmed/25606127.

17. Troncon LE de A. Ensino clínico na comunidade. Med Ribeirão Preto 1999;32:335-44.

18. Berwanger J, Denti De Geroni G, Bonamigo EL. Estudantes de Medicina na percepção dos pacientes. Rev. bioét. 2015;23(3):55262 [acesso em 20 nov 2018]. Disponível em: http://dx.doi. org/10.1590/1983-80422015233092.

19. Pedraza DF, Santos I. Perfil e atuação do agente comunitário de saúde no contexto da Estratégia Saúde da Família em dois municípios da Paraíba. Interações 2017;18(3):97 - 105 [acesso em 15 mar 2018]. Disponível em: http://www.scielo.br/pdf/inter/v18n3/1518-7012inter-18-03-0097.pdf

20. Albuquerque VS, Gomes AP, Rezende CHA de, Sampaio MX, Dias OV, Lugarinho RM. A integração ensino-serviço no contexto dos processos de mudança na formação superior dos profissionais da saúde. Rev. bras. educ. med. 2008;32(3):356-62.

21. Massote AW, Belisário SA, Gontijo ED. Atenção primária como cenário de prática na percepção de estudantes de Medicina. Rev. bras. educ. med. 2011;35(4):445-53.

\section{AUTHORS' CONTRIBUTION}

Moniquelly Barbosa da Silva: performed the literature review, data collection, transcription of the interview material, data analysis, interpretation and writing of the manuscript.

Izabel Rios: data analysis and interpretation of findings, writing and review of the manuscript.

Pedro Félix Vital Júnior: data analysis, interpretation of results and writing of the manuscript.

Andréa Tenório Correia da Silva: study design and supervision, analysis of the transcribed material, interpretation of results, writing and revision of the manuscript.

\section{CONFLICTS OF INTEREST}

The authors declare no conflict of interest.

\section{ADDRESS FOR CORRESPONDENCE}

Andréa Tenório Correi da Silva. I. Faculdade Santa Marcelina, Núcleo de Pesquisa em Atenção Primária e Ciência da Implementação (NUPAScience). Rua Cachoeira de Itupanema, 40 - Vila Carmosina, São Paulo - SP, 08270-140. II. Departamento de Medicina Preventiva, Faculdade de Medicina da Universidade de São Paulo. Av. Dr. Arnaldo, 455, Cerqueira César, São Paulo - SP, CEP 01246903. Departamento de Medicina Preventiva, Sala 2221.

E-mail: andreatenorio@usp.br

ANNEX 1 - In-depth interview scripts

\section{Interview script with health professionals}

(1) In your opinion, what is it like to have a medical student on your family health team?;

(2) Did you receive any advice on how to welcome medical students on your team?;

(3) Do you think the presence of medical students on the Team has brought any changes? Why?;

(4) In your opinion, what are the difficulties of teaching medical students in the Basic Health Unit?;

(5) In your opinion, what could be improved to favor the teaching of medical students?

(6) What do you think the BHU should teach medical students for them to become good doctors?

(7) What do you think could be modified to improve the students' learning? 